\title{
Primary infertility: characteristics of women in North America according to pathological findings
}

\author{
Valerie Beral, Robert Rolfs, M Riduan Joesoef, Sevgi Aral, D W Cramer
}

\begin{abstract}
Study objective - To determine, in women with primary infertility, whether specific characteristics or behavioural factors are associated with the various pathological conditions identified as contributing to the infertility.
\end{abstract}

Design - Case-control study.

Setting - Seven institutions in the USA or Canada.

Participants - Study subjects were 1750 women who presented with primary infertility, among whom the main pathological cause of infertility was male factor (417), tubal obstruction (231), endometriosis (194), luteal phase defects (153), other ovulatory problems (193), cervical abnormalities (92), and polycystic ovarian disease (84) and 1765 control women who delivered their first child at the same institution.

Main results - Except for tubal obstruction and polycystic ovarian disease, the characteristics and behaviours of the women with infertility did not differ appreciably according to the pathological conditions recorded. Women with tubal obstruction had had more sexual partners, an earlier age at first intercourse, were more likely to have used an intrauterine device but less likely to have used a condom, and were more likely to have smoked cigarettes and to have used various recreational drugs than the other women. Women with polycystic ovarian disease were more obese, had had fewer sexual partners, and were less likely to have used cigarettes, contraceptives, and recreational drugs than the other women.

Conclusions - Sexually transmitted infections seem to increase the risk of tubal obstruction but not other causes of infertility. Obesity is associated with polycystic ovarian disease. These data offer few clues to the aetiology of infertility attributed to endometriosis, cervical abnormalities, luteal phase defects, other ovulatory defects, or to male factors.

\section{(f Epidemiol Community Health 1994;48:576-579)}

About one in 10 couples of reproductive age in the USA are classified as infertile. ${ }^{1}$ Investigations of the causes of infetility have generally focussed on identifying the associated pathological lesions in both the man and woman. Little is known about risk factors for the different underlying pathological conditions or whether the lesions themselves have different external causes. The main exception is tubal obstruction, which has been linked to previous tubal infection probably as a result of sexually transmitted infections and use of an intrauterine device. ${ }^{23}$

As part of a study of the relationship between contraceptive use and tubal infertility, data were collected on all couples who consulted for infertility at seven infertility centres in the USA from January 1981 to June $1983 .^{2}$ The women and their partners were investigated clinically and the pathological conditions identified as contributing to their infertility were diagnosed and recorded according to a standard protocol.

We describe here the characteristics of women who presented with primary infertility according to the various pathological conditions identified. This investigation aimed to assess whether the classification of women according to the pathological conditions associated with their infertility identifies separate groups with distinct characteristics. If so, this would suggest that the various conditions have different external causes, and the characteristics of the women might provide clues to the aetiology of those conditions.

\section{Methods}

The detailed study design has been reported elsewhere. ${ }^{3}$ Briefly, the study population consisted of 1818 infertile women who, between January 1981 and June 1983, presented to one of seven institutions in the USA or Canada with infertility and 2817 women without a history of infertility who, between April 1981 and September 1983, delivered a live-born child as a result of a planned pregnancy at the same institutions (Brigham and Women's Hospital; New England Fertility and Gynecology Associates; the University of Vermont; the University of Colorado, the University of Kentucky, the University de Sherbrooke, and George Washington University). Both groups were interviewed using an identical questionnaire. It contained detailed information on sociodemographic factors; menstrual and reproductive history; past health; sexual activity; contraceptive use; smoking history; use of marijuana, cocaine and other recreational drugs; the consumption of alcohol, coffee, and other 
Table 1 Main diagnoses in 1750 couples who presented with primary infertility

\begin{tabular}{lc}
\hline Main diagnosis & No (\%) of couples \\
\hline Tubal obstruction & $231(13)$ \\
Endometriosis & $194(11)$ \\
Cervical abnormalities & $92(5)$ \\
Luteal phase defects & $153(9)$ \\
Polycystic ovaries & $84(5)$ \\
Other ovulatory problems & $193(11)$ \\
Male factor & $417(24)$ \\
Other identified conditions & $208(12)$ \\
No cause found & $178(10)$ \\
Total & $1750(100)$ \\
\hline
\end{tabular}

drinks; and on other habits. The main aim of the study was to investigate the relationship between use of intrauterine devices and infertility but data were collected to study other determinants of fertility. Reports on the relation of infertility to contraceptive use, cigarette smoking, and caffeine have already been published..$^{3-7}$

More than one condition could be recorded as contributing to infertility, and if so, the collaborating gynaecologists were asked to list the conditions in order of their importance. Most of the data presented here are for the condition listed first. This first diagnosis listed will sometimes be referred to as the "main cause" of infertility. All analyses conducted were also restricted to couples who had only one condition recorded and also for couples with any mention of each specific condition. Unless specifically mentioned, the results did not differ materially from those reported here.

The analyses here were restricted to the 1750 women who presented with primary infertility and 1765 fertile "control" women who de- livered their first child at the same institutions. Comparisons of means and proportions were made between those with each specific condition and (i) all remaining infertile women and (ii) control women using the computer program, SAS.

\section{Results}

Table 1 shows the distribution of the main pathological diagnoses recorded for the 1750 couples who presented with infertility. The largest group, representing one quarter of the total, are those for whom a male factor was specified as the main cause of infertility. Tubal obstruction, endometriosis, luteal phase defects, and other ovulatory problems each accounted for about one tenth of the diagnoses; and polycystic ovarian syndrome and cervical abnormalities each contributed about $5 \%$ of the diagnoses. Other identified conditions accounted for $12 \%$ of the remaining diagnoses, although no single cause was common enough to consider separately. In the remaining $10 \%$ of couples no pathological cause could be found for their infertility. Since the main purpose of these analyses was to compare groups who presented with different identified pathological conditions, the couples with "other identified conditions" and "no cause found" are excluded from subsequent analyses.

Many couples had more than one abnormality recorded (table 2). This was especially so for couples whose main cause of infertility was luteal phase defects or tubal obstruction and was least common for couples

Table 2 Additional diagnoses that were recorded as contributing to infertility, according to the main diagnosis recorded in 1750 couples who presented with primary infertility

\begin{tabular}{|c|c|c|c|c|c|c|c|c|}
\hline \multirow[t]{2}{*}{ Main diagnoses } & \multirow{2}{*}{$\begin{array}{l}\% \text { with more } \\
\text { than one } \\
\text { contributory } \\
\text { condition }\end{array}$} & \multicolumn{7}{|c|}{ Second diagnoses (no) } \\
\hline & & $\begin{array}{l}\text { Tubal } \\
\text { obstruction }\end{array}$ & Endometriosis & $\begin{array}{l}\text { Cervical } \\
\text { abnormalities }\end{array}$ & $\begin{array}{l}\text { Luteal } \\
\text { phase } \\
\text { defects }\end{array}$ & $\begin{array}{l}\text { Polycystic } \\
\text { ovaries }\end{array}$ & $\begin{array}{l}\text { Other } \\
\text { ovulatory } \\
\text { problems }\end{array}$ & $\begin{array}{l}\text { Male } \\
\text { factor }\end{array}$ \\
\hline \multirow{6}{*}{$\begin{array}{l}\text { Tubal } \\
\text { obstruction } \\
\text { Endometriosis } \\
\text { Cervical } \\
\text { abnormality } \\
\text { Luteal phase } \\
\text { defects } \\
\text { Polycystic } \\
\text { ovaries } \\
\text { Other ovulatory } \\
\text { problems } \\
\text { Male factor }\end{array}$} & & & & & & & & \\
\hline & $\begin{array}{l}45 \\
31\end{array}$ & $\begin{array}{r}1 \\
10\end{array}$ & $\begin{array}{r}10 \\
0\end{array}$ & $\begin{array}{r}13 \\
0\end{array}$ & $\begin{array}{l}18 \\
13\end{array}$ & $\begin{array}{l}2 \\
2\end{array}$ & $\begin{array}{l}8 \\
8\end{array}$ & $\begin{array}{l}33 \\
27^{*}\end{array}$ \\
\hline & 34 & 3 & 4 & 0 & 7 & 0 & 2 & 8 \\
\hline & 46 & 7 & 13 & 10 & 0 & 2 & 4 & 25 \\
\hline & 24 & 2 & 0 & 4 & 1 & 0 & 1 & 10 \\
\hline & $\begin{array}{l}31 \\
39\end{array}$ & $\begin{array}{r}9 \\
17\end{array}$ & $\begin{array}{c}6 \\
31^{*}\end{array}$ & $\begin{array}{l}10 \\
11\end{array}$ & $\begin{array}{c}4 \\
45^{*}\end{array}$ & $\begin{array}{r}1 \\
14\end{array}$ & $\begin{array}{c}1 \\
26^{*}\end{array}$ & $\begin{array}{r}25 \\
0\end{array}$ \\
\hline
\end{tabular}

${ }^{*} \mathrm{p}<0.05$ for second diagnosis occurring more frequently than expected on the basis of the distributions of second diagnoses in all other infertile couples.

Table 3 Sociodemographic characteristics of 1750 women who presented with primary infertility, according to the main diagnosis

\begin{tabular}{|c|c|c|c|c|c|c|c|c|}
\hline Characteristic & $\begin{array}{l}\text { Tubal } \\
\text { obstruction } \\
(n=231)\end{array}$ & $\begin{array}{l}\text { Endometriosis } \\
(n=194)\end{array}$ & $\begin{array}{l}\text { Cervical } \\
\text { abnormalities } \\
(n=92)\end{array}$ & $\begin{array}{l}\text { Luteal } \\
\text { phase } \\
\text { defect } \\
(n=153)\end{array}$ & $\begin{array}{l}\text { Polycystic } \\
\text { ovaries } \\
(n=84)\end{array}$ & $\begin{array}{l}\text { Other } \\
\text { ovulatory } \\
\text { problems } \\
(n=193)\end{array}$ & $\begin{array}{l}\text { Male } \\
\text { factor } \\
(n=417)\end{array}$ & $\begin{array}{l}\text { Controls } \\
(n=1765)\end{array}$ \\
\hline $\begin{array}{l}\text { Mean age }(y) \\
\text { Mean years of }\end{array}$ & $30 \cdot 0$ & $30 \cdot 4$ & $30 \cdot 3$ & $30 \cdot 9$ & $27 \cdot 1^{*}$ & $28 \cdot 5$ & $29 \cdot 5$ & $28 \cdot 2$ \\
\hline $\begin{array}{l}\text { education completed } \\
\text { Income }(\%) \text { : }\end{array}$ & $14 \cdot 3$ & $15 \cdot 2$ & $14 \cdot 7$ & $15 \cdot 8^{*}$ & $13 \cdot 8^{*}$ & $14 \cdot 6$ & $14 \cdot 3$ & $15 \cdot 0$ \\
\hline $\begin{array}{l}\quad<\$ 15,000 \\
\geqslant \$ 30,000 \\
\text { Ever consulted } \\
\text { elsewhere for infertility }\end{array}$ & $\begin{array}{l}10 \\
45\end{array}$ & $\begin{array}{r}5^{*} \\
58^{*}\end{array}$ & $\begin{array}{c}9 \\
56^{*}\end{array}$ & $\begin{array}{c}7 \\
58^{*}\end{array}$ & $\begin{array}{l}24^{*} \\
30^{*}\end{array}$ & $\begin{array}{l}10 \\
47\end{array}$ & $\begin{array}{l}10 \\
49\end{array}$ & $\begin{array}{l}11 \\
49\end{array}$ \\
\hline $\begin{array}{l}\text { Mean no of } \\
\text { months attempting }\end{array}$ & 63 & $80^{*}$ & 72 & 69 & 67 & 65 & 64 & 0 \\
\hline to conceive & $47 \cdot 5^{*}$ & $43 \cdot 5$ & $40 \cdot 5$ & $37 \cdot 6^{*}$ & $43 \cdot 2$ & $39 \cdot 0$ & $44 \cdot 9$ & $5 \cdot 5$ \\
\hline
\end{tabular}

* Differs significantly from controls $(p<0 \cdot 05)$ and from other infertile women $(p<0.05)$. 
Table 4 Characteristics and behaviours of 1750 women who presented with primary infertility

\begin{tabular}{|c|c|c|c|c|c|c|c|c|}
\hline \multirow[t]{2}{*}{ Characteristics } & \multicolumn{8}{|c|}{ Cause of infertility } \\
\hline & $\begin{array}{l}\text { Tubal } \\
\text { obstruction } \\
(n=231)\end{array}$ & $\begin{array}{l}\text { Endometiosis } \\
(n=194)\end{array}$ & $\begin{array}{l}\text { Cervical } \\
\text { abnormalities } \\
(n=92)\end{array}$ & $\begin{array}{l}\text { Luteal } \\
\text { phase } \\
\text { def } \\
(n=153)\end{array}$ & $\begin{array}{l}\text { Polycystic } \\
\text { ovaries } \\
(n=84)\end{array}$ & $\begin{array}{l}\text { Other } \\
\text { ovulatory } \\
\text { problems } \\
(n=193)\end{array}$ & $\begin{array}{l}\text { Male } \\
\text { factor } \\
(n=417)\end{array}$ & $\begin{array}{l}\text { Controls } \\
(n=1765)\end{array}$ \\
\hline $\begin{array}{l}\text { Mean weight (lb) } \\
\text { Mean height (in) } \\
\text { Engaged in regular }\end{array}$ & $\begin{array}{c}129 \\
64 \cdot 3\end{array}$ & $\begin{array}{c}127 \\
64.9\end{array}$ & $\begin{array}{l}125 \\
64 \cdot 2\end{array}$ & $\begin{array}{c}131 \\
64 \cdot 5\end{array}$ & $\begin{array}{c}145^{*} \\
64 \cdot 0\end{array}$ & $\begin{array}{r}137^{*} \\
64 \cdot 6\end{array}$ & $\begin{array}{c}131 \\
64 \cdot 5\end{array}$ & $\begin{array}{c}127 \\
64 \cdot 5\end{array}$ \\
\hline $\begin{array}{l}\text { vigorous exercise }(\%) \\
\text { Smoking }(\%) \text { : }\end{array}$ & 41 & 44 & 33 & $55^{*}$ & 37 & 39 & 39 & 50 \\
\hline $\begin{array}{l}\text { Never } \\
\text { Current } \\
\text { Drug use }(\%) \text { : }\end{array}$ & $\begin{array}{l}42 \\
36^{*}\end{array}$ & $\begin{array}{l}57 \\
22\end{array}$ & $\begin{array}{l}47 \\
33\end{array}$ & $\begin{array}{l}50 \\
27\end{array}$ & $\begin{array}{l}61^{*} \\
25\end{array}$ & $\begin{array}{l}58 \\
28\end{array}$ & $\begin{array}{l}49 \\
28\end{array}$ & $\begin{array}{l}52 \\
15\end{array}$ \\
\hline $\begin{array}{l}\text { Ever cocaine } \\
\text { Ever amphetamine } \\
\text { Ever LSD } \\
\text { Regular marijuana }\end{array}$ & $\begin{array}{l}21^{*} \\
26^{*} \\
16^{*} \\
30^{*}\end{array}$ & $\begin{array}{r}10 \\
13 \\
8 \\
11\end{array}$ & $\begin{array}{r}15 \\
12 \\
7 \\
17\end{array}$ & $\begin{array}{r}14 \\
20 \\
9 \\
20\end{array}$ & $\begin{array}{c}10 \\
7^{*} \\
1^{*} \\
17\end{array}$ & $\begin{array}{r}10 \\
11 \\
7 \\
13\end{array}$ & $\begin{array}{r}10 \\
12 \\
7 \\
12\end{array}$ & $\begin{array}{r}14 \\
14 \\
9 \\
18\end{array}$ \\
\hline $\begin{array}{l}\text { Mean no of } \\
\text { contraceptive methods } \\
\text { ever used } \\
\text { Type of contraceptive } \\
\text { method ever used (\%): }\end{array}$ & $1 \cdot 6$ & $1 \cdot 8$ & 1.5 & $1 \cdot 7$ & $1 \cdot 2^{*}$ & $1 \cdot 4$ & $1 \cdot 5$ & $1 \cdot 8$ \\
\hline $\begin{array}{l}\text { Spermicide } \\
\text { Condom } \\
\text { Diaphragm } \\
\text { Pill } \\
\text { IUD }\end{array}$ & $\begin{array}{l}10 \\
27^{*} \\
29 \\
68 \\
30^{*}\end{array}$ & $\begin{array}{l}13 \\
39 \\
30 \\
77 \\
16\end{array}$ & $\begin{array}{l}11 \\
36 \\
23 \\
71 \\
12\end{array}$ & $\begin{array}{l}14 \\
32 \\
39 \\
72 \\
12\end{array}$ & $\begin{array}{c}8 \\
29^{*} \\
17^{*} \\
56^{*} \\
11^{*}\end{array}$ & $\begin{array}{r}8 \\
33 \\
22 \\
68 \\
12\end{array}$ & $\begin{array}{r}8 \\
30 \\
28 \\
69 \\
14\end{array}$ & $\begin{array}{r}9 \\
42 \\
40 \\
70 \\
20\end{array}$ \\
\hline $\begin{array}{l}\text { Mean no of previous } \\
\text { pregnancies } \\
\text { Mean frequency of }\end{array}$ & 0.5 & $0 \cdot 3$ & $0 \cdot 3$ & 0.5 & $0 \cdot 2$ & $0 \cdot 3$ & $0 \cdot 2$ & $0 \cdot 4$ \\
\hline $\begin{array}{l}\text { intercourse per week } \\
\text { Mean age at first } \\
\text { intercourse (y) } \\
\text { Mean age at first }\end{array}$ & $18 \cdot 5^{*}$ & $19 \cdot 5$ & $19 \cdot 5$ & $19 \cdot 7$ & $18 \cdot 9$ & $19 \cdot 4$ & $19 \cdot 6$ & $19 \cdot 3$ \\
\hline $\begin{array}{l}\text { regular intercourse }(y) \\
\text { Mean no of sexual } \\
\text { partners }\end{array}$ & $\begin{array}{l}20 \cdot 5 \\
6 \cdot 4^{*}\end{array}$ & $21 \cdot 0$ & $21 \cdot 3$ & $21 \cdot 7$ & $19 \cdot 9$ & $20 \cdot 8$ & $21 \cdot 0$ & $20 \cdot 9$ \\
\hline
\end{tabular}

${ }^{*}$ Differs significantly from controls $(p<0.05)$ and from other infertile women $(p<0.05)$.

with polycystic ovarian disease. The distribution of second diagnoses did not differ appreciably according to the main cause of infertility. Four combinations of diagnoses occurred more often than expected by chance alone. These were endometriosis as the main diagnosis together with male factor as a second diagnosis; and male factor as a main diagnosis together with endometriosis, luteal phase defects, or other ovulatory disorders as the second diagnoses.

The age, educational attainment, and income of the women who consulted with primary infertility varied little according to the main pathological cause of their infertility, except for women with polycystic ovarian disease (table 3), who tended to be younger, have fewer years of schooling, and to have lower incomes than the other infertile women. Women with endometriosis, cervical abnormalities, and luteal phase defects had higher incomes than the average. Two thirds of the women in all diagnostic groups had already consulted elsewhere for infertility at the time of interview, and women with endometriosis were more likely to have done so than the others. The average time the couples had attempted to conceive was 40 months: those with tubal disease had tried for longer and those with luteal phase defects had tried for a shorter time than the others.

Other characteristics of the women, such as their weight, exercise history, reported smoking and drug use, use of contraceptives, and sexual practices were generally similar across the various pathological causes of infertility, except for the women with tubal obstruction or with polycystic ovarian disease (table 4 ). Women with tubal obstruction were more likely to smoke cigarettes, to have used various recreational drugs, to have used intrauterine de- vices, and to have had more sexual partners and an earlier age at first intercourse and were less likely to have used condoms than the others. Women with polycystic ovarian disease were heavier and were less likely to smoke, use recreational drugs or contraceptives, and to have fewer sexual partners than the other women with infertility. Women with luteal phase defects were more likely than other women to report that they engaged in regular vigorous exercise.

The results presented in tables 3 and 4 are given according to main pathological cause of infertility recorded. Since one third of the couples had at least one additional diagnosis, the analyses were repeated for couples with only a single diagnosis. The results were generally similar to those presented here.

\section{Discussion}

These data indicate that, with two exceptions, the characteristics of women who consult for primary infertility do not differ appreciably according to the pathological conditions identified as contributing to their infertility. The exceptions are tubal obstruction and polycystic ovarian disease. Women with each of these conditions differ from other infertile women and from fertile women in many respects. Tubal obstruction and polycystic ovarian disease are therefore two distinct types of infertility and are likely to have external causes which differ from the causes of infertility in other couples.

Tubal disease has already been linked to past tubal infections and to the use of the intrauterine devices. ${ }^{23}$ The findings that the women with tubal disease had begun intercourse earlier, had had more sexual partners, and used condoms less frequently than other 
infertile women support the view that sexually transmitted infections probably contribute to the tubal infection and subsequent obstruction.

Little is known about the aetiology of polycystic ovarian disease, except for its link with obesity, which is confirmed here. The reasons for its associations with low income, few sexual partners, and infrequent use of contraceptives, cigarettes, and recreational drugs are unclear although all might be related to the women's obesity. Indeed, polycystic ovarian disease may itself be a consequence of obesity. Clearly there is a need to study the aetiology of this condition in some detail.

Women with luteal phase defects were more likely to report that they engaged regularly in vigorous exercise than the other women. This could be a chance finding or could represent a true effect of exercise on ovarian function and therefore deserves further study.

Sexually transmitted diseases have been thought to contribute to other types of infertility, such as to various cervical abnormalities in infertile women, but the fact that the characteristics of women with other types of infertility are not similar to those of women with tubal obstruction suggests that sexually transmitted infections are probably not important causes of the other types of infertility.

Endometriosis, cervical abnormalities, and luteal phase defects tend to be diagnosed in women of relatively high income (table 1). This could reflect different consulting patterns according to socioeconomic status. ${ }^{1}$ Otherwise, the present analysis offers few clues to the aetiology of many of the well recognised pathological lesions associated with infertility.

We thank Susan Shaw and Sarah Jones for typing the manuscript.

1 Aral SO, Cates $\mathrm{W}$. The increasing concern with infertility fAMA 1983;250:2327-331.

2 Daling JR, Weiss NS, Metch BJ, et al. Primary tubal infertility in relation to the use of an intrauterine device. New Engl f Med 1985;312:937-41.

3 Cramer DW, Schiff I, Schoenbaum SC, et al. Tubal infertility and the intrauterine device. New Engl f Med 1985;312: 941-7.

4 Phipps WR, Cramer DW, Schiff I, et al. The association between smoking and female infertility as influenced by cause of the infertility. Fertility and Sterility 1987;48:377-82. 5 Cramer DW, Goldman MB, Schiff I, et al. The relationship of tubal infertility to barrier method and oral contraceptive
use. $\mathcal{F} A M A 1987 ; 257: 2446-50$.

6 Cramer DW, Wilson E, Stillman RJ, et al. The relation of endometriosis to menstrual characteristics, smoking, and exdometriosis to menstrual characteris.

7 Joesoef MR, Beral V, Rolfs RT, et al. Are caffeinated beverages risk factors for delayed contraception? Lancet 1990;335:
$136-7$. 